\title{
Knowledge, Attitudes and Practice of Undergraduate Students in University of Nigeria Enugu campus (UNEC) towards Hepatitis B
}

\author{
Kosisochi Chinwendu Amorha", Martin Ifeanyi Chiebue, Ebere Emilia Ayogu, \\ Onyinye Blessing Ukoha-Kalu, Mathew Jegbefume Okonta \\ (Department of Clinical Pharmacy and Pharmacy Management, Faculty of Pharmaceutical Sciences, University \\ of Nigeria, Nsukka, Enugu State, Nigeria)
}

\begin{abstract}
Undergraduate students represent a population that is at high-risk for acquiring and spreading hepatitis $B$ infection $(H B V)$. This study was designed to evaluate the knowledge, attitudes and practice of undergraduate students in the University of Nigeria Enugu Campus (UNEC) towards Hepatitis B. During April to May 2014, a cross-sectional and descriptive survey was conducted amongst undergraduate students of UNEC. A 33-item structured questionnaire on statements concerning knowledge base of $H B V$, attitudes and practices towards hepatitis B were distributed to 360 students. Statistical analysis was carried out with the Statistical Package for Social Sciences (SPSS) v 16.0 using the independent sample's t-test and ANOVA test with level of significance set at $P \leq 0.05$. Majority had heard of hepatitis (93.0\%) and hepatitis B (89.9\%). Less than half (35.9\%) thought they could get hepatitis B infection. Only $25.6 \%$ had gone for a hepatitis B screening and just $33.0 \%$ had been vaccinated against $\mathrm{HBV}$. Out of the 360 respondents, $97.2 \%, 10 \%$ and $24.4 \%$ had good knowledge, positive attitudes and good practice, respectively. The students of health sciences had significantly better practice in hepatitis B than the students of business administration [1.89 (95\% CI; 1.67 2.11) versus 1.46 (95\% CI; $1.19-1.73) ; F=3.072 ; p=0.05]$. The results of this study reveal that overall, undergraduate students of UNEC had good knowledge on hepatitis and hepatitis B but this translated neither to favourable attitudes nor good practices.
\end{abstract}

Keywords: Attitudes, Hepatitis B, Knowledge, Practice, Undergraduate Students

\section{Introduction}

Hepatitis B virus (HBV) causes both acute and chronic disease of the liver, contributing to the global health burden by claiming the lives of an estimated 0.78 million people yearly [1,2]. Although HBV has high transmissibility through contact with the body fluids of an infected person, it is preventable with available vaccines [1]. Nigeria is in Sub-Saharan Africa where the prevalence of HBV is highest [2]. Most liver cirrhosis and liver cancer cases in sub-Saharan Africa are attributable to HBV [3]. Unfortunately, Nigeria has lower vaccination rates against HBV than many Sub-Saharan African countries [4].

Undergraduate students are majorly youths who may be sexually active. They are usually required when there is need for blood donation [5]. Also, medical students are at high risk to get and spread HBV during their professional training because their activities involve contact with patients or body fluids [6]. A high proportion of medical students in a Saudi Arabian study showed poor knowledge about HBV and those with good knowledge had the highest vaccination rates [7]. Studies have shown a positive correlation between the attitudes towards HBV and mean knowledge level of hepatitis B patients and the healthy population $[8,9]$.

Although many studies in various countries have been conducted, there have been very few attempts to evaluate the knowledge, attitudes and practice of Nigerian undergraduates regarding HBV. The general objective of this study was to evaluate the knowledge, attitudes and practice of undergraduate students in University of Nigeria Enugu Campus (UNEC) towards hepatitis B.

\section{Methods}

This study was a cross-sectional and descriptive survey carried out in the University of Nigeria Enugu Campus (UNEC) between April and May, 2014. This campus is located in the heart of Enugu, the administrative capital of Enugu State in South-Eastern Nigeria. The faculties in UNEC are: Business Administration, Environmental Studies, Law, Health Sciences and Medical Sciences.

Respondents for this research were conveniently sampled from Medical Sciences, Health Sciences and Business Administration with two departments from each of the selected faculties. These totaled 2248 students from the six departments. Students in their first year of study were excluded from the survey.

The sample size was calculated from the total population using the Raosoft ${ }^{\circledR}$ sample size calculator to be 329 students, at 5\% error margin and 95\% confidence interval [10]. An overage of 40 students was added to bring the sample size to 360 students. 
The instrument was a self-administered 33-item structured questionnaire adapted from an already validated questionnaire [9]. This questionnaire was developed through extensive literature review in English language [9]. The questionnaire was also piloted with 30 respondents to ensure there was no ambiguity. Results of the pilot study were not included in the final analysis and the respondents were not included in the study. In addition to the demographic data, 22 questions explored knowledge towards HBV, 7 questions were on attitude and 5 questions addressed practices towards HBV. Questions were on a binary response and Likert-scale, as appropriate. Confidentiality was maintained and the respondents were informed that they had the right to withdraw from the survey at any time.

Ethical approval was sought for and obtained from the Health Research and Ethics Board of the University of Nigeria Teaching Hospital (UNTH), Ituku-Ozalla, Enugu, Enugu State prior to the commencement of the study.

Data was coded and entered into the Statistical Package for Social Sciences (SPSS) Windows version 16.0 (SPSS Inc, Version 16.0, Chicago, USA) for analysis. Descriptive statistics were used to illustrate the demographic characteristics. Categorical variables were measured as percentages while continuous variables were expressed as mean (standard deviation). The independent sample's t-test and ANOVA test were performed with level of significance set at $\mathrm{P} \leq 0.05$.

\section{Results}

A total of three hundred and sixty questionnaires were distributed with a $100 \%$ response rate. There was an almost equal distribution of males and females who participated in this study with males being slightly higher $(51.7 \%)$. Majority of the respondents were within the age bracket of 21 to 30 years (71.5\%). Only $21.8 \%$ of the participating students were from the Faculty of Business Administration. See table 1.

Table 2 describes the knowledge of hepatitis among the respondents. Knowledge was assessed by asking questions about aetiology, types, symptoms, modes of transmission, complications, management and vaccination against hepatitis virus. Each response was scored as 'yes' or 'no'. Majority of the respondents had heard of hepatitis $(93.0 \%)$ and hepatitis B (89.9\%). Only $62.1 \%$ of them knew that there are five major subtypes of hepatitis. However, 59.0\% of the respondents knew that hepatitis B can be transmitted from unsterilized barber's clipper.

Most of the respondents agreed that hepatitis B patients should either go to a health professional, $(94.8 \%)$ or visit a health facility $(94.0 \%)$. As many as $55.6 \%$ believed that the diagnosis and treatment of hepatitis B is expensive. Less than half (35.9\%) thought they could get hepatitis B infection. See table 3.

Only $25.6 \%$ of the respondents had gone for a hepatitis B screening and just $33.0 \%$ had been vaccinated against HBV. See table 4.

Knowledge scores were summed up to give the total knowledge score for each respondent. Knowledge score ranged from 0 (minimum) to 44 (maximum). These knowledge scores were categorized such that those who scored above $70 \%$ had good knowledge of hepatitis B. The attitude scores ranged from 0 (minimum) to 12 (maximum). Respondents who had above $60 \%$ of the total attitude scores were categorized as having positive attitudes. The practice scores ranged from 0 (minimum) to 5 (maximum). Respondents who had above $70 \%$ of the total practice scores were categorized as exhibiting good practice. Out of the 360 respondents, $97.2 \%, 10 \%$, and $24.4 \%$ were in the good knowledge, positive attitudes and good practice range, respectively. Based on gender, females had a statistically significant better knowledge of hepatitis B than their male counterparts [38.82 (95\% CI; -1.32 to 0.12 ) versus 38.22 (95\% CI; -1.33 to 0.13$) ; \mathrm{p}=0.02$ ]. Higher scores on knowledge indicated better knowledge of hepatitis B. The medical sciences and health sciences did not significantly differ in knowledge on hepatitis B. However, the students of medical sciences showed significantly better knowledge of hepatitis B than the students of business administration [39.06 (95\% CI; 38.57 to 39.56) versus 37.86 (95\% CI; $36.95-38.76) ; \mathrm{F}=3.937 ; \mathrm{p}=0.02$ ]. Also, higher scores in practice signified good practice. The medical sciences and health sciences did not significantly differ in practice. However, the students of health sciences had significantly better practice in hepatitis B than the students of business administration [1.89 (95\% CI; $1.67-2.11)$ versus $1.46(95 \% \mathrm{CI} ; 1.19-1.73) ; \mathrm{F}=3.072 ; \mathrm{p}=0.05]$. See table 5 for more details.

Correlations were interpreted using the following criteria: $0-0.25=$ weak correlation; $0.25-0.5=$ fair correlation; $0.5-0.75=$ good correlation and greater than $0.75=$ excellent correlation [11]. The correlation revealed significant positive linear correlation between knowledge-attitude $(r=0.178, p<0.01)$. There was a significant negative linear correlation between attitude-practice $(r=-0.274, p<0.001)$. See table 6 for more details. 


\section{Discussion}

The results of this study reveal that undergraduate students of UNEC have good knowledge of hepatitis but negative attitudes and poor practice towards hepatitis B.

Majority of the students had heard of hepatitis and hepatitis B. They also had good knowledge on hepatitis B. This may be due to the rising prevalence of hepatitis B in Nigeria [2]. In a study among the healthy population of Quetta, Pakistan $97.8 \%$ and $84.0 \%$ had heard of hepatitis and hepatitis B respectively but had poor knowledge about hepatitis B [9]. This could be that people may have heard of a disease state without necessarily having good knowledge about it. Other studies showed poor knowledge levels of different populations from different regions [12-14]. However, a study among medical and health science students in an Ethiopian university showed 56.2\% had adequate knowledge about hepatitis B [15]. In an academic environment that has medically-inclined students and lecturers, there may have been awareness, seminars or campaigns on hepatitis. In addition, the University of Nigeria offers General Studies courses in the first and second years of the university. These courses cover issues on health for those who are not in science or health-related departments.

More than half of the students had good knowledge that hepatitis B can be transmitted from unsafe sex. This differs from other studies where less than $20 \%$ of the respondents correctly answered that hepatitis B can be transmitted through sexual intercourse $[9,14]$. In a university environment, knowledge of possible transmission of HBV through unsafe sexual practices is important since majority of the students are youths and may be subject to influence by peer pressure. Students should be informed regarding the importance of abstinence or safe sexual practices.

Only a little below half of the students disagreed that the diagnosis and treatment of hepatitis B is expensive. Similarly, a study in Pakistan showed that only $8.8 \%$ of the respondents believed the diagnosis and treatment of HBV is expensive [8]. This belief may deter students from doing tests for the virus or those who have been diagnosed may not seek treatment. This might not stem from ignorance as more than $80 \%$ of them were knowledgeable about the treatment of hepatitis B and prophylaxis with vaccines. The cost of treatment may also force patients to seek help from traditional healers and some less credible sources. We recommend that the government, non-governmental organizations and pharmaceutical companies can help with making tests, vaccines and treatment available and affordable for the majority of Nigerians. Free health checks for HBV and seminars can be sponsored to educate students and prevent the further spread of the infection. These could be conducted on university campuses and participants should be advised on what to do if any tests positive.

Many of the students did not think they could be infected with hepatitis B. This might negatively influence their taking precautionary measures. Almost all the students agreed that persons with symptoms suggestive of hepatitis B or patients who already have HBV should seek the services of health professionals. However, a large proportion opined that people with hepatitis B may express fear, shame, surprise or sadness. This is buttressed in a study where isolation from the society was the biggest fear among hepatitis B patients, surpassing the fear of death; the fear of disease spread to family; even the cost of treatment [8].

Despite having good knowledge on the availability of vaccines for hepatitis B infection, only a quarter of the respondents had gone for screening on hepatitis B with just $33 \%$ being vaccinated. This may contribute to the high prevalence of HBV infection due to lack of preventive measures. The fear of injection may also contribute to the negative immunization status. Other studies have also shown many respondents with no screening on hepatitis B and a negative immunized status $[9,14]$. A study in a Nigerian tertiary institution had $11.5 \%$ of the 200 students screened testing positive for HBV [16]. This is a concern as this cohort is eligible for blood donation. Screening and vaccination is important for all students especially those of medical and health sciences who may be exposed to blood and blood products as well as at risk of acquiring needle stick injury in their professional practice. These students could even be screened and vaccinated prior to commencing their academic programmes.

Only about a quarter of the students claimed to have ever participated in health education programs related to hepatitis B. This is surprising as the students from the health sciences and medical sciences comprised close to $80 \%$ of the entire respondents. In these programs, students may be encouraged to screen for HBV and get vaccinated. It is possible that they may have participated in health education programs related to other disease states as Nigeria is in a malaria-endemic region and saddled with various tropical and chronic diseases. Educational programs on HBV are strongly recommended for both healthy individuals and hepatitis B patients. [8]. The mass media could give better coverage. Interestingly, more than $80 \%$ agreed they would go for further investigation and treatment if they were diagnosed with hepatitis B.

Few of the respondents revealed that they avoid meeting hepatitis B patients. This differs from another study where majority (81.4\%) would prefer to have nothing to do with hepatitis B patients [9]. Stigmatization of hepatitis B patients should be avoided. During health educational programs, people should be taught not only on the ways to avoid being infected but also how to favourably deal with infected patients.

Based on gender, females had a statistically significant better knowledge of hepatitis B than their male counterparts. The medical sciences and health sciences did not significantly differ in knowledge and practice on 
hepatitis B. However, the faculty of business administration fared less than the medical sciences and health sciences in knowledge and practice respectively. This might be as a result of their area of focus which is neither health nor medical.

There was a statistically significant positive correlation between knowledge and attitude, though weak. This infers that good knowledge may not strongly reflect positive attitudes towards hepatitis B. This contradicts very many studies that showed a positive correlation between knowledge, attitude and practice [8-9, 17]. Also, the weak negative relationship between attitude and practice which was statistically significant showed that as attitudes became positive, practice got poorer. People may not practice what they say or claim to believe in.

This study was questionnaire-based and the self-reported information provided by the respondents is subjective. It was conducted in University of Nigeria Enugu Campus and the results may not be representative of other faculties or campuses in other universities.

\section{Conclusion}

The findings of this study indicate that undergraduate students in UNEC had good knowledge on hepatitis and hepatitis B but this did not translate to favourable attitudes or good practices. Extensive health promotion efforts on hepatitis B should be conducted periodically on campuses to improve knowledge, encourage favourable attitudes and good practices.

\section{Acknowledgements}

The authors are thankful to the study participants. The researchers have no competing interests to declare. The study was self-funded.

\section{References}

[1]. World Health Organization (WHO). Hepatitis B [monograph on the internet]. 2015. [cited 2016 Mar 29]. Available from: http://www.who.int/immunization/diseases/hepatitisB/en/.

[2]. World Health Organization (WHO). Hepatitis B. Fact sheet [monograph on the internet]. 2015. [cited 2016 Mar 30]. Available from: http://www.who.int/mediacentre/factsheets/fs204/en/.

[3]. J.F. Perz, G.L. Armstrong, L.A. Farrington, Y.J. Hutin, and B.P. Bell. The contributions of hepatitis B virus and hepatitis C virus infections to cirrhosis and primary liver cancer worldwide, Journal of Hepatology, 45, 2006, 529-538.

[4]. B. Musa, S. Bussell, M.M. Borodo, A.A. Samaila and O.L. Femi. Prevalence of hepatitis B virus infection in Nigeria, 2000-2013: A systematic review and meta-analysis, Nigerian Journal of Clinical Practice, 18, 2015, 163-172.

[5]. I. Isa, M. Aminu, S.A. Abdullahi, M.A. Sani, and D.E. Akafyi. Seroprevalence of hepatitis B virus in a tertiary institution in North Western Nigeria, African Journal of Microbiology Research, 9, 2015, 171-179.

[6]. A.H. Al-Hazmi. Knowledge, attitudes, and practice of medical students regarding occupational risks of hepatitis b virus in college of medicine, Aljouf University, Annals of Medical and Health Sciences Research, 5,2015, 13-19.

[7]. S.M. Othman, A.M. Saleh, N.P. Shabila. Knowledge about hepatitis B infection among medical students in Erbil city, Iraq, European Scientific Journal, 3, 2013, 299-305.

[8]. N. ul Haq, M.A. Hassali, A.A. Shafie, F. Saleem, M. Farooqui, A. Haseeb, H. Aljadhey. A cross-sectional assessment of knowledge, attitude and practice among Hepatitis-B patients in Quetta, Pakistan, BMC Public Health, 13, 2013, 448.

[9]. N. ul Haq, M.A. Hassali, A.A. Shafie, F. Saleem, M. Farooqui, H. Aljadhey. A cross sectional assessment of knowledge, attitude and practice towards Hepatitis B among healthy population of Quetta, Pakistan, BMC Public Health, 12, 2012, 692.

[10]. Raosoft Sample Size Calculator. [Cited 2016 Mar 30]. Available from: http://www.raosoft.com/samplesize.html.

[11]. J. Cohen. Statistical power analysis for the behavioural sciences. In second edition edited by Hillsdale NJ. New Jersey: Lawrence Erlbaum 1988

[12]. T.T. Nguyen, V. Taylor, M.S. Jr Chen, R. Bastani, A.E. Maxwell, and S.J. McPhee. Hepatitis B awareness, knowledge, and screening among Asian Americans, Journal of Cancer Education, 22, 2007, 266-272.

[13]. [Y.J.J. van der Veen, H.A.C.M. Voeten, O. de Zwart, and J.H. Richardus. Awareness, knowledge and self-reported test rates regarding Hepatitis B in Turkish-Dutch: a survey, BMC Public Health, 10, 2010, 512.

[14]. G. Haider and A. Haider. Awareness of women regarding hepatitis B. Journal of Ayub Medical College, Abbattabad, 20, 2008, 141144.

[15]. Y.M. Mesfin, K.T. Kibret. Assessment of knowledge and practice towards hepatitis B among medical and health science students in Haramaya university, Ethiopia. PLoS ONE, 8, 2013, e79642-e79642.

[16]. G.R. Pennap, O. Nwachukwu, D. Ishakelu, and R.J. Ombugadu. Hepatitis B virus carriage among students of a Nigerian tertiary institution: A cohort of eligible blood donors. Research Journal of Medical Sciences, 5, 2011, 90-93.

[17]. R. Mansour-Ghanaei, F. Joukar, F. Souti, and Z. Atkar-Roushan. Knowledge and attitude of medical science students towards hepatitis B and C infections. International Journal of Clinical and Experimental Medicine, 6, 2013, 197-205. 


\section{Tables}

Table 1: Demographics of participating students, $N=360$

\begin{tabular}{|c|c|}
\hline Variables & n (\%) \\
\hline \multicolumn{2}{|l|}{ Gender } \\
\hline Male & $183(51.7)$ \\
\hline Female & $171(48.3)$ \\
\hline \multicolumn{2}{|l|}{ Age (Years) } \\
\hline $18-20$ & $95(26.8)$ \\
\hline $21-30$ & $253(71.5)$ \\
\hline $31-40$ & $6(1.7)$ \\
\hline \multicolumn{2}{|l|}{ Faculty } \\
\hline Health Sciences & $124(34.6)$ \\
\hline Business Administration & $78(21.8)$ \\
\hline Medical Sciences & $156(43.6)$ \\
\hline \multicolumn{2}{|l|}{ Study Year } \\
\hline 2nd Year & $107(29.8)$ \\
\hline 3rd Year & $97(27.0)$ \\
\hline 4th Year & $88(24.5)$ \\
\hline 5th Year & $67(18.7)$ \\
\hline
\end{tabular}

Table 2: Knowledge of hepatitis among participating students, $\mathrm{N}=360$

\begin{tabular}{|c|c|}
\hline Question/Statement (Correct Option) & $\begin{array}{l}\text { Number of } \quad \text { Correct } \\
\text { Responses }(\%)\end{array}$ \\
\hline 1. Have you ever heard of hepatitis? (Yes) & $331(93.0)$ \\
\hline 2. Have you ever heard of hepatitis B? (Yes) & $321(89.9)$ \\
\hline 3. Hepatitis infection is caused by virus (Yes) & $282(85.5)$ \\
\hline 4. Hepatitis infections have five sub-types (Yes) & $182(62.1)$ \\
\hline 5. Hepatitis infection can affect liver function (Yes) & $308(91.9)$ \\
\hline 6. Hepatitis infection can cause liver cancer (Yes) & $235(76.8)$ \\
\hline 7. Hepatitis infection can affect any particular age group (Yes) & $186(58.3)$ \\
\hline 8. Hepatitis B is the most common of hepatitis infections (Yes) & $270(84.9)$ \\
\hline 9. The early symptoms of hepatitis are same for cold and flu (fever, running nose, cough) (Yes) & $203(69.8)$ \\
\hline 10. Jaundice is one of the major symptoms of hepatitis B (Yes) & $239(78.9)$ \\
\hline 11. Nausea, vomiting and loss of appetite are common symptoms of hepatitis B (Yes) & $248(82.9)$ \\
\hline 12. All hepatitis B patients experience symptoms at the early stage of the disease (No) & $183(60.8)$ \\
\hline 13. Hepatitis B can be transmitted from unsterilized sharp objects, surgical instruments (Yes) & $205(65.9)$ \\
\hline 14. Hepatitis B can be transmitted from unsterilized barber's clipper (Yes) & $184(59.0)$ \\
\hline 15. Hepatitis B can be transmitted from contaminated blood and blood products (Yes) & $246(79.4)$ \\
\hline 16. Hepatitis B can be transmitted from unsafe sex (Yes) & $192(61.7)$ \\
\hline 17. Hepatitis B can be transmitted from mother to child (Yes) & $187(62.5)$ \\
\hline $\begin{array}{l}\text { 18. Hepatitis B can be transmitted from contaminated water/food prepared by a person suffering } \\
\text { from the infection (No) }\end{array}$ & $157(51.8)$ \\
\hline 19. Hepatitis B is curable/treatable (Yes) & $254(82.7)$ \\
\hline 20. Hepatitis B can be self-cured by the body (No) & $181(62.0)$ \\
\hline 21. Vaccination is available for Hepatitis B infection (Yes) & $242(80.1)$ \\
\hline 22. Specific diet is required for the treatment of Hepatitis B (Yes) & $179(61.7)$ \\
\hline
\end{tabular}

Table 3: Attitudes of participating students towards hepatitis B

\begin{tabular}{|l|l|}
\hline Statements & Agree, n (\%) \\
\hline Fear, shame, surprise, sadness are reactions found in people with hepatitis B & $217(70.2)$ \\
\hline Hepatitis B patients should always go to the health professional & $308(94.8)$ \\
\hline Patients suspecting hepatitis B should always go to the health facility & $295(94.0)$ \\
\hline It is better to go to the health facility as soon as one suspects symptoms of hepatitis B & $298(93.5)$ \\
\hline The diagnosis and treatment of hepatitis B is expensive & $167(55.6)$ \\
\hline Hepatitis B vaccination should be compulsory for every individual & $264(83.5)$ \\
\hline
\end{tabular}

Table 4: Participating students' practices and screening behaviours towards hepatitis B

\begin{tabular}{|l|l|l|}
\hline Questions & Yes, n (\%) & No, n (\%) \\
\hline Have you ever gone for a screening on hepatitis B? & $82(25.6)$ & $235(74.4)$ \\
\hline Have you got yourself vaccinated against hepatitis B? & $104(33.0)$ & $211(67.0)$ \\
\hline Do you avoid meeting hepatitis B patients? & $71(22.7)$ & $242(77.3)$ \\
\hline In case you are diagnosed with hepatitis B, would you go for further investigation and treatment? & $262(82.4)$ & $56(17.6)$ \\
\hline Have you ever participated in a health education programme related to hepatitis B? & $93(29.8)$ & $219(70.2)$ \\
\hline
\end{tabular}

Note: Only 108 respondents (35.9\%) thought they could get hepatitis B 
Knowledge, Attitudes and Practice of Undergraduate Students in University of Nigeria Enugu campus

Table 5: Comparisons of student demographics and their mean knowledge, attitude and practice scores

\begin{tabular}{|c|c|c|c|c|c|c|c|}
\hline Variable & $\mathbf{N}$ & Knowledge score & p-value & Attitude score & p-value & Practice score & p-value \\
\hline \multicolumn{8}{|l|}{ Gender* } \\
\hline Male & 183 & $27.86(3.91)$ & \multirow[b]{2}{*}{0.01} & $10.08(1.32)$ & \multirow[b]{2}{*}{0.72} & $1.58(1.16)$ & \multirow[b]{2}{*}{0.41} \\
\hline Female & 171 & $\begin{array}{c}27.22(3.16) \\
(95 \% \mathrm{CI} ;-0.11 \text { to } \\
1.38)\end{array}$ & & $\begin{array}{c}10.34(1.12) \\
(95 \% \mathrm{CI} ;-0.52 \\
\text { to }-0.01)\end{array}$ & & $\begin{array}{c}1.90(1.22) \\
(95 \% \mathrm{CI} ;- \\
0.56 \text { to }-0.07)\end{array}$ & \\
\hline \multicolumn{8}{|l|}{ Age, years** } \\
\hline $18-20$ & 95 & $\begin{array}{l}27.63(3.87)(95 \% \\
\text { CI; } 26.84 \text { to } 28.42)\end{array}$ & \multirow{3}{*}{0.23} & $\begin{array}{c}10.35(1.51) \\
(95 \% \mathrm{CI} ; 10.04 \\
\text { to } 10.65)\end{array}$ & \multirow{3}{*}{0.35} & $\begin{array}{c}1.66(1.15) \\
\text { (95\% CI; } 1.43 \\
\text { to } 1.90)\end{array}$ & \multirow{3}{*}{0.14} \\
\hline $21-30$ & 253 & $\begin{array}{l}27.48(3.48)(95 \% \\
\text { CI; } 27.05 \text { to } 27.91)\end{array}$ & & $\begin{array}{c}10.15(1.12) \\
(95 \% \mathrm{CI} ; 10.01 \\
\text { to } 10.21)\end{array}$ & & $\begin{array}{c}1.74(1.19) \\
(95 \% \text { CI; } 1.59 \\
\text { to } 1.88)\end{array}$ & \\
\hline $31-40$ & 6 & $\begin{array}{l}30.00(2.28)(95 \% \\
\text { CI; } 27.61 \text { to } 32.39)\end{array}$ & & $\begin{array}{c}10.50(1.05) \\
(95 \% \mathrm{CI} ; 9.40 \\
\text { to } 11.60)\end{array}$ & & $\begin{array}{c}2.67(1.51) \\
(95 \% \text { CI; } 1.09 \\
\text { to } 4.25)\end{array}$ & \\
\hline \multicolumn{8}{|l|}{ Faculty** } \\
\hline Health Sciences & 124 & $\begin{array}{l}27.85(3.44)(95 \% \\
\text { CI; } 27.24 \text { to } 28.47)\end{array}$ & \multirow[t]{3}{*}{0.05} & $\begin{array}{c}10.28(1.09) \\
(95 \% \mathrm{CI} ; 10.09 \\
\text { to } 10.48)\end{array}$ & \multirow[t]{3}{*}{0.15} & $\begin{array}{c}1.89(1.24) \\
(95 \% \mathrm{CI} ; 1.67 \\
\text { to } 2.11)\end{array}$ & \multirow[t]{3}{*}{0.05} \\
\hline Medical Sciences & 156 & $\begin{array}{c}27.05(3.38)(95 \% \\
\text { CI; } 26.52 \text { to } 27.59)\end{array}$ & & $\begin{array}{c}10.25(1.30) \\
(95 \% \text { CI; } 10.04 \\
\text { to } 10.46)\end{array}$ & & $\begin{array}{c}1.74(1.14) \\
\text { (95\% CI; } 1.56 \\
\text { to } 1.92) \\
\end{array}$ & \\
\hline $\begin{array}{c}\text { Business } \\
\text { Administration }\end{array}$ & 78 & $\begin{array}{l}28.14(4.02)(95 \% \\
\text { CI; } 27.23 \text { to } 29.05)\end{array}$ & & $\begin{array}{c}9.96(1.27) \\
(95 \% \text { CI; } 9.67 \\
\text { to } 10.25)\end{array}$ & & $\begin{array}{c}1.46(1.20) \\
(95 \% \text { CI; } 1.19 \\
\text { to } 1.73) \\
\end{array}$ & \\
\hline \multicolumn{8}{|l|}{ Study year** } \\
\hline $2^{\text {nd }}$ & 107 & $\begin{array}{l}28.14(4.13)(95 \% \\
\text { CI; } 27.35 \text { to } 28.93)\end{array}$ & \multirow{4}{*}{0.03} & $\begin{array}{l}10.17(1.14) \\
(95 \% \mathrm{CI} ; 9.95 \\
\text { to } 10.39)\end{array}$ & \multirow{4}{*}{0.80} & $\begin{array}{c}1.62(1.17) \\
\text { (95\% CI; } 1.39 \\
\text { to } 1.84)\end{array}$ & \multirow{4}{*}{0.07} \\
\hline $3^{\text {rd }}$ & 97 & $\begin{array}{l}26.93(3.41)(95 \% \\
\text { CI; } 26.24 \text { to } 27.62)\end{array}$ & & $\begin{array}{c}10.16(1.55) \\
\text { (95\% CI; } 9.85 \\
\text { to } 10.48)\end{array}$ & & $\begin{array}{c}1.55(1.18) \\
\text { (95\% CI; } 1.31 \\
\text { to } 1.78)\end{array}$ & \\
\hline $4^{\text {th }}$ & 88 & $\begin{array}{l}28.00(3.54)(95 \% \\
\text { CI; } 27.25 \text { to } 28.75)\end{array}$ & & $\begin{array}{c}10.32(1.02) \\
(95 \% \mathrm{CI} ; 10.10 \\
\text { to } 10.54)\end{array}$ & & $\begin{array}{l}1.95(1.25) \\
\text { (95\% CI; } 1.69 \\
\text { to } 2.22)\end{array}$ & \\
\hline $5^{\text {th }}$ & 67 & $\begin{array}{l}26.97(2.53)(95 \% \\
\text { CI; } 26.35 \text { to } 27.59)\end{array}$ & & $\begin{array}{c}10.20(1.23) \\
(95 \% \mathrm{CI} ; 9.89 \\
\text { to } 10.44)\end{array}$ & & $\begin{array}{c}1.87(1.14) \\
\text { (95\% CI; } 1.59 \\
\text { to } 2.14)\end{array}$ & \\
\hline
\end{tabular}

Mean scores are represented as Mean (Standard Deviation); Tests conducted *student t-test (for dichotomous variables) and **ANOVA (for three or more categories). $\mathrm{P} \leq 0.05$ indicated statistical significance

Table 6: Correlation between knowledge, attitude and practice

\begin{tabular}{|c|c|c|}
\hline Variable & Correlation coefficient & P-value \\
\hline Knowledge-attitude & 0.154 & $<0.01$ \\
\hline Knowledge-practice & 0.023 & 0.66 \\
\hline Attitude-practice & 0.29 & $<0.001$ \\
\hline
\end{tabular}

$\mathrm{P} \leq 0.05$ is statistically significant 